\title{
BUSH V. GORE AND THE FRENCH REVOLUTION: A TENTATIVE LIST OF SOME EARLY LESSONS
}

\author{
SANFORD LEVINSON*
}

\begin{abstract}
I
INTRODUCTION

Simon Schama begins his magisterial book on the French Revolution, Citizens, by relating the reply of Chinese Premier Zhou En-lai to a question about the significance of those 1789 events: "It's too soon to tell." One suspects that Zhou's emphasis on the importance of a long-term perspective is especially jolting to Americans, who inhabit a culture that generally waits until no later than Monday to engage in their analysis of weekend events. I am confident, for example, that many (perhaps most) readers remember watching television newscasts on the evening of December 12, 2000, which featured, toward the close of day, images of couriers for the various networks racing down the Supreme Court steps, followed within minutes by immediate analysis of the meaning of the Court's opinion in Bush v. Gore. ${ }^{2}$ More recently, the truly awful events of September 11, 2001, which have cast a broad shadow over all of our lives, generated hours upon hours of experts not only opining that our lives will be fundamentally transformed, which I am sure is the case, but also, and more problematically, specifying the transformations that will shape our future.
\end{abstract}

Copyright (C) 2002 by Sanford Levinson

This article is also available at http://www.law.duke.edu/journals/65LCPLevinson.

* W. St. John Garwood and W. St. John Garwood, Jr. Centennial Chair in Law and Professor of Government, University of Texas, Austin. An earlier version of this article was given as the 2001 Brainard Currie Lecture; it also served to "keynote" the conference on "The Law of Politics," a daunting task because of the participation in the conference of a number of people who know far more about the details of the subject than I do, especially my friend and former colleague Sam Issacharoff, from whom I have learned much about election law. I am grateful to Jack Balkin for his long conversations on an earlier draft and to Philip Bobbit, Walter Dellinger, Garrett Epps, Steven Gutstein, Larry Kramer, Cynthia Levinson, Rachel Levinson, H.W. Perry, Richard Posner, David Rabban, Chris Schroeder, Mark Tushnet, and Alan Wolfe for their extremely helpful responses to earlier drafts. Given the tone of some of my remarks, it should be emphasized that I did not accept all the advice they gave and that they bear no responsibility for whatever readers might find objectionable (or even problematic) in what follows.

I should also note that some of the themes in Part Three of the present essay were first set forth in a Henry J. Miller Distinguished Lecture at the Georgia State University Law School, published as Why It's Smart to Think About Constitutional Stupidities, 17 GA. ST. U. L. REV. 359 (2000).

1. Simon Schama, Citizens xiii (1989). Schama does not indicate who asked the question. My colleague Philip Bobbitt has said that he has heard the question attributed to the then-radical French writer Régis Debray.

2. 531 U.S. 98 (2000). 
It is good, therefore, to be reminded of the importance of adopting a longer perspective and to realize that it is difficult to know, with any confidence, what the importance and durable consequences of any given event actually may be. One need not be a full-fledged historicist to recognize that any full description or assessment of event $X$ ultimately depends on knowing future events, which will inevitably throw a different light on the past; because of this change in lighting, we see details of earlier events that had earlier seemed relatively unimportant, just as previously high-lit actors fade into insignificance to be replaced by what we mistakenly thought were bit players or even simply extras. And, as Chekhov taught us, an apparently unimportant gun over the mantle that we perceive only as part of the background scenery when the curtain rises may eventually turn out to generate catastrophic consequences by the conclusion of the play.

Consider in this context, for example, what one might want to say, in a symposium commemorating the fortieth anniversary of Baker v. Carr, ${ }^{3}$ the case in which the Supreme Court overruled a fifteen-year-old precedent ${ }^{4}$ and held, contrary to the earlier case, that legislative districting did in fact present an issue capable of judicial resolution under the Fourteenth Amendment. ${ }^{5}$ Had that symposium been scheduled for October 2000, I dare say that it would never have occurred to me or to any other participant to address the possibility that the ultimate consequence of Baker and of the "one person-one vote" doctrine adopted two years later in Reynolds $v$. Sims ${ }^{6}$ and its progeny would be the empowerment of the Supreme Court to take charge of a national presidential election and, in effect, to bring the election to a halt by declaring the winner. No one today, however, can be unaware of the "presidential-election strand" of doctrine. This means that any overall assessment of the significance of the Court's decision to enter what Justice Frankfurter in Colegrove v. Green so memorably called the "political thicket" of legislative apportionment must surely include the role it played in (ostensibly) legitimizing the decision almost four decades later in Bush v. Gore.

It is not surprising, then, that Schama seems to endorse Zhou's caution by writing that "[t]wo hundred years may still be too soon" to offer any confident analysis of an historical event. ${ }^{8}$ More surprising, perhaps is Schama's interposi-

3. 369 U.S. 186 (1962).

4. Colegrove v. Green, 328 U.S. 549 (1946).

5. Just such a symposium was held at the University of North Carolina School of Law on November 3, 2001. See Sanford Levinson, One Person/One Vote: A Mantra in Need of Meaning, 80 N.C. L. REV. (forthcoming May 2002).

6. 377 U.S. 533 (1964). Actually, the first appearance of the term was in Gray v. Sanders, 372 U.S. 368, 381 (1963) ("The conception of political equality from the Declaration of Independence, to Lincoln's Gettysburg Address, to the Fifteenth, Seventeenth, and Nineteenth Amendments can mean only one thing-one person, one vote."). This case struck down Georgia's "county-unit" system of electing its governors, but it was obviously Reynolds that demonstrated the fundamental importance of the term in transforming American politics.

7. 328 U.S. 549, 556 (1946).

8. SCHAMA, supra note 1 , at xiii. 
tion of the words "[or] possibly, too late" to tell." We are left, then, with the rueful knowledge not only that we can never in fact tell what is the truly right time to offer an analysis of a complex event, but also that any given moment in time is likely to be "wrong" from at least one plausible perspective. Still, just as we are faced with the existential task of using the particular slice of time that we inhabit to give whatever meaning we can to our own lives, in spite of our knowledge that future events may make a mockery of our projects (and of us for engaging in them), so is it true with interpreting the history that frames our lives. We must confront the great public events of our lives and offer, with due humility, our best analysis of them, whatever our certainties that those analyses will inevitably be limited and may, indeed, turn out to be flatly wrong.

The authors in this symposium all examine the "law of politics." It is probably less important than fundamental questions of war and peace that currently confront us or, even more certainly, of basic physical survival, but from another perspective it possesses its own transcendent importance. A basic difference, we properly believe, between the U.S. political system and that of our adversaries is the emphasis we place on popular governance and democratic politics, even as we might vigorously differ among ourselves on the precise implications of what "We the People" means with regard to organizing our polity. Indeed, the opportunity to differ so vigorously is among the most precious "blessings of liberty" that are indeed worth fighting for.

As we try to figure out the consequences of Bush v. Gore, the only certainty is that it is far too early to tell whether it was a decision good for that day only, as suggested to many by the carefully hedged words of the per curiam opinion itself, ${ }^{10}$ or whether it will serve as the fount for a new body of "the law of politics" that may surprise friend and foe alike. This being said, I am nonetheless interested in sharing some very preliminary suggestions as to the meaning and consequences of the decision for anyone interested, as we all are, in the "law of politics."

I must emphasize (or confess) one assumption at the foundation of much of what follows: I believe that the opinions offered to justify the decision to halt the Florida recount are grievously mistaken as standard-form exercises in legal analysis. I incorporate by reference Harvard law professor Joel Parker's assessment of arguments made by defenders of some of Abraham Lincoln's exercise of power during the events of 1861 to 1865 . These arguments were, said Parker, "[a] tissue of miserable sophistry, bad law, and if possible, worse logic." 11 Nothing that has been said since December 12, 2000, has changed my

9. Id.

10. See 531 U.S. at 100 ("Our consideration is limited to the present circumstances ...."); David A. Strauss, Bush v. Gore: What Were They Thinking, 68 U CHI. L. REV. 737, _ (2001), reprinted in THE Vote: Bush, Gore \& The Supreme CourT 184, 199 (Cass R. Sunstein \& Richard A. Epstein eds., 2001) ("The Court's attempt to limit its holding, with barely a fig leaf of principle, gives the game away. The majority was not concerned with principle.").

11. Quoted in Phillip S. Paludan, A Covenant with Death: The Constitution, Law, AND EQUALITY IN THE CIVIL WAR ERA 146 (1975). 
initial view that Parker's denunciation is altogether applicable to the decision handed down on that day. However, I will not in this article even begin to defend this view. All I will do is cite several fine articles by such luminaries as Jack Balkin, ${ }^{12}$ David Strauss, ${ }^{13}$ Frank Michelman, ${ }^{14}$ Richard Hasen, ${ }^{15}$ Laurence Tribe, ${ }^{16}$ and Richard Briffault ${ }^{17}$ that demonstrate for me the appropriateness of adopting Parker's description.

I realize that some readers may vigorously disagree. Some of you may even agree with Nelson Lund, who has written of "The Unbearable Rightness of Bush v. Gore" ${ }^{, 18}$ and defended every last jot and tittle of the Supreme Court's opinion. ${ }^{19}$ For better and for worse, it is not my purpose on this occasion to rehash these arguments. My purpose, instead, is to offer, with suitable tentativeness, some of the lessons that I think I learned in the first ten months of life after Bush v. Gore. ${ }^{20}$

I want to use Bush v. Gore as an entry-point into understanding American constitutional culture(s). One way of summarizing my lessons is first, that "law," as we ordinarily think of it, may be much less important than we might believe (or hope) with regard to controlling politics, but, second, that law, as we rarely think of it, may have us gripped within a constitutional iron cage that makes it next to impossible to engage in a cogent discussion of what might ail the contemporary American polity and, concomitantly, what might be needed by way of reforms.

12. Jack M. Balkin, Bush v. Gore and the Boundary Between Law and Politics, 110 YALE L.J. 2407 (2001).

13. Strauss, supra note 10 , at 184.

14. Frank I. Michelman, Suspicion, or the New Prince, 68 U. CHI. L. REV. 679 (2001), reprinted in THE VoTE: Bush, GORE \& THE SUPREME COURT, supra note 10, at 123.

15. Richard Hasen, Bush v. Gore and the Future of Equal Protection Law in Elections, 29 FLA. ST. U. L. REV. 377 (2001).

16. Laurence H. Tribe, Comment: Erog .v Hsub and its Disguises: Freeing Bush v. Gore from its Hall of Mirrors, 115 HARV. L. REV. 170 (2001). (2001).

17. Richard Briffault, Bush v. Gore as an Equal Protection Case, 29 FLA. ST. U. L. REV. 325

18. Nelson Lund, The Unbearable Rightness of Bush v. Gore, 23 CARDOZO L. REV. (forthcoming Feb. 2002).

19. As opposed to, as with some conservatives, defending only the Article II argument adopted by Chief Justice Rehnquist and joined in by Justices Scalia and Thomas. See, e.g., RICHARD A. POSNER, BREAKING THE DEADlock: THE 2000 Elections, THE CONSTITUTION, AND THE COURTS 153-58 (2001).

20. These remarks were obviously written before the Currie Lecture, delivered in October, 2001. I am revising them for this article. Although a central thesis of this article is that the decision will be analyzed differently as time passes and provides different perspectives from which to assess it, I cannot say that anything has happened in the intervening months to change my mind. It is clearly the case, though, that George Bush's performance as a "war President," and his rhetorical invocation, at every opportunity, of that status, have tended to make "academic" the debate over the merits of the decision. Those of us who continue really to care about it (and who indicate, as I do, significant doubts about Bush's competence to be President) are ever more viewed, I suspect, either as cranks or, even worse, subversives. Whatever else may have been the consequences of September 11, one must recognize that Osama bin Laden brought to a close, as a practical matter, the debate about the legitimacy of George Bush's presidency. 
I structure my remarks around the answers to three questions that for me are central to any assessment of the particular "constitutional moment" that is Bush v. Gore.

\section{II}

\section{How SERIOUSLy CAN WE TAKE THE POSSIBILITY OF DISINTERESTED LEGAL ANALYSIS?}

It is my experience that American constitutional lawyers, whether practitioners, academics, or judges, seem to feel relatively few genuine constraints in the kinds of arguments they are willing to make or endorse. It is, I am confident, harder to recognize a "frivolous argument" in constitutional law than in any other area of legal analysis. Almost all constitutional analysts, as a matter of brute fact, seem committed to a de facto theory of "happy endings," whereby one's skills as a rhetorical manipulator of what my colleague Philip Bobbitt terms the "modalities" of legal argument ${ }^{21}$ are devoted to achieving satisfying results.

One of the things that some of us learned on December 12, 2000, was that five Republican Justices ${ }^{22}$ - that is, Justices with a pre-judicial affiliation with the Republican Party who were appointed by Republican Presidents-were willing to do whatever it took to shut down the electoral process in Florida in a context where that meant the inevitable occupation of the White House by the Republican candidate, George W. Bush. But we also learned that four other Justices, ${ }^{23}$ two of them Democrats appointed by a Democratic President, the other two, given developments since their appointments, probably better identified as "nominal" Republicans rather than, say, "median" Republicans, were willing to support an election process that, at the time, was thought to favor the Democratic candidate, Al Gore. At least one dissenting Justice agreed with the majority that there were indeed substantial equal protection violations presented by the Florida election process but stated, rather remarkably, that this did not warrant the Supreme Court even granting review in the case. ${ }^{24}$ And, of course, James Baker, joined by many other Republicans, had earlier strongly implied

21. Philip Bobbitt, Constitutional Interpretation (1991).

22. Chief Justice Rehnquist and Justices Scalia, Thomas, O'Connor, and Kennedy.

23. Justices Ginsburg, Souter, Stevens and Breyer.

24. Note that Justice Souter did not make this argument within the context of a doctrine of "political questions" that would have declared the questions raised by the Florida election inappropriate for judicial resolution per se. He said only that "[i]f this Court had allowed the State to follow the course indicated by the opinions of its own Supreme Court, it is entirely possible that there would ultimately have been no issue requiring our review, and political tension could have worked itself out in the Congress following the procedure provided in 3 U.S.C. § 15.” Bush v. Gore, 531 U.S. 98, 129 (2000). This appears to be a (quite defensible) prudential judgment, but, of course, one's judgment about what prudence required is itself significantly determined by one's politics. Justice Breyer was a bit more evasive as to the merits, writing that "in these very special circumstances, basic principles of fairness may well have counseled the adoption of a uniform standard to address the problem." Id. at 146 (emphasis added). As any lawyer knows, the italicized words are rather fudgy, allowing the writer to defer actual commitment to the proposition asserted. Justice Breyer began his opinion by stating, "The Court was wrong to take this case." Id. at 144. 
that the Florida Supreme Court was simply an arm of the Democratic Party in much the way that the state apparatus was, for Lenin, merely the ruling committee of the bourgeoisie.

No reader is unaware of the fact that the legal academy is rent by precisely the same political divides as the Supreme Court (save that the majority of the legal academy remains solidly liberal-and therefore?-antagonistic to the decision). ${ }^{25}$ Some of us, including myself, have publicly described the United States Supreme Court in terms similar to those that James Baker-without justification, I believe-applied to the Florida Supreme Court. ${ }^{26}$ What this means, then, is that the differences of opinion in evaluating Bush v. Gore may serve further to discredit the very notion of a "disinterested" analysis of law and, therefore, of the validity of analyses offered with regard to such a volatile topic as "the law of politics." In speaking of "the law of politics," we know that what we are ultimately talking about is not only how we should select those who will hold political power-which includes, often, literal power over life and deathbut also, as a practical matter, who is more likely to hold power. None of us can plausibly claim to be living within a Rawlsian veil of ignorance that leaves us unaware of the practical consequences of given changes for our favorite political party or interest group.

To the extent that no one-or, perhaps more accurately, very few-on either side of the debate seem willing to grant genuine respect to both the Florida Supreme Court and the United States Supreme Court, or to both the majority and dissenters within those respective courts, it seems equally difficult to establish a way within the academy for proponents of radically different views genuinely to engage with one another. Instead, we are all tempted to move fairly quickly to viewing (and treating) one's intellectual opponents as either fools or knaves. I will confess that this is sometimes the posture I myself take, for example, with regard to the Article II argument that is posited as a defense for the Court's decision. This argument relies on that part of Article II, section 1, that states: "Each state shall appoint, in such Manner as the Legislature thereof may direct, a Number of Electors ...."27 This language was used first to discredit the opinions of the Florida Supreme Court and then to justify the possibility that the Florida legislature would indeed "appoint" the Florida electors, regardless of whatever might be suggested by any recount of the ballots. My lack of char-

25. If proof is needed of this proposition, just look at the articles in THE VOTE: BUSH, GORE \& THE SUPREME COURT, supra note 10, where liberal scholars like Frank I. Michelman and David A. Strauss offer sharply different accounts from those given by conservatives Richard A. Epstein and John

C. Yoo. But see infra note 45 for the presence of some exceptions to this generalization.

26. See, e.g., Alan M. Dershowitz, Supreme Injustice: How The High Court Hijacked ELECTION 20004 (2001) (suggesting that the votes of the majority are best conceived as "the partisan question for immediate political victory"); Randall Kennedy, Contempt of Court, AM. ProsPECT, Jan. 1, 2001, at XX, reprinted in BUSH V. GORE: THE COURT CASES AND THE COMMENTARY 336 (E.J. Dionne Jr. \& William Kristol eds., 2001) ("The Gang of Five showed themselves to be a cadre of downfield blockers committed to clearing away any last-minute impediments to the ascendancy of George W. Bush").

27. U.S. CONST. art. II, $\S 1, \mathrm{cl} .2$. 
ity, no doubt, is due at least in part to the fact that that argument is founded upon a characterization of the Florida Supreme Court as a group either of blithering fools or of patently dishonest partisan hacks. Moreover, this argument has the consequence of ignoring the recount and legitimizing an effort by the Florida legislature to deprive the people of Florida of the right to have their own ballots, instead of the legislature, choose their presidential electors. ${ }^{28}$

I am not unaware that many people disagree with me! Indeed, they might describe me as similarly "foolish" for my failure to perceive the merits of the Article II argument and my blindness to the "fact" that the majority of the Florida Supreme Court was indeed composed of either knaves or fools. But, some might suggest, it is not really that I am foolish, but rather that I am a knave, so caught up in a mixture of support for Al Gore (for whom I voted) and antagonism to the Republican Party (which I in fact possess) that I willfully subordinate my obvious capacities for disciplined legal analysis to my political agenda. In so doing, my critics might say, I dishonor the high office that I hold, which is that of law professor, committed to offering at least as disinterested an analysis of constitutional issues as that which is expected of judges. This means, among other things, that we should, to whatever extent possible, try to tame at least our baser political instincts. ${ }^{29}$

I take it that my description rings true to anyone within the legal academy. One of my interests is how this division and accompanying acrimony will challenge certain postures adopted by the legal academy over the years with regard to the enterprise of "reforming" the law, including, of course, that particular branch of the law that directly structures the political process. The traditional reform mission of law professors-as distinguished from, say, professors of political science-has two elements. The first involves what might be termed "belief in law," that is, the assertion that there exist internalist approaches to legal analysis that are importantly different from other modes of analysis, including straightforward policy analysis. It is this that justifies what remains the "standard-form" law review article that consists primarily of the exegesis of decided cases, usually by the United States Supreme Court, and the drawing from these

28. The argument also requires ignoring other important parts of the Constitution's text, including Article IV, section 4 (the "Republican Form of Government Clause"); the Fourteenth Amendment, section 2 (referring to "the right to vote at any election for the choice of electors for President and Vice President of the United States"); and the Seventeenth Amendment ("The Senate of the United States shall be ... elected by the people."). As to this last text, I find it inconceivable that the members of Congress who proposed the Amendment would not have included presidential electors had they even imagined the possibility that purportedly serious lawyers, even at the turn of the twentieth century, would argue that the state legislature, no longer empowered to appoint senators, could in fact appoint presidential electors.

29. As I have argued elsewhere, there is an important difference between "high politics," which includes what Felix Frankfurter once called those "idealized political pictures," Felix Frankfurter, Supreme Court, United States, 14 ENCY. SOC. SCI. 480 (1st ed. 1939), that judges (like the rest of us) carry in their heads and which structure political reality and a "low politics" that emphasizes whether one's friends or opponents win a given political contest. See Jack M. Balkin \& Sanford Levinson, Understanding the Constitutional Revolution, 87 VA. L. REV. 1045, 1062-63 (2001). 
cases, ostensibly through disciplined techniques of legal analysis, the correct messages with regard to the future shape of the law.

The second characteristic of traditional law-reform proposals is that they must appear "sensible," that is, they must be basically only incremental changes from the status quo. If the changes involved are more than just incremental, including changes that would require formal amendment of the constitutional text, then we have moved into the realm of what might be called "constitutional design," a topic about which lawyers may have almost nothing useful to say (once again, as distinguished from political scientists). I shall discuss this first element now, turning to the second at the end of my remarks.

My friend Paul Carrington, the Chadwick Professor of Law at the Duke Law School, wrote a notable article some seventeen years ago about the decline within the academy of what he viewed as a requisite level of belief or faith in law as a distinct and valuable way of thinking about social problems. ${ }^{30}$ Instead, he argued, an increasing number of law professors were busy reducing law to something else. The most important such reduction, for Carrington, was politics, a view identified with legal scholars in the then-energized Critical Legal Studies movement, but also present, in substantial ways, in the work of their primary antagonists, the "law-and-economics" movement emanating from the University of Chicago Law School. It was, after all, the most distinguished member of that movement who titled one of his many books Overcoming Law. ${ }^{31}$ Although Critical Legal Studies as a movement is moribund these days, there is certainly no reason to believe that the view that Carrington attacked has substantially abated since he wrote in the 1980s. Indeed, one immediate response to Bush v. Gore was precisely some version of "the crits were right after all"; in other words, that "legal analysis" is simply the achievement of one's political desires dressed up in obfuscating rhetoric. ${ }^{32}$

One might, in this context, ponder the fascinating debate between Geoffrey Stone, former Dean of the University of Chicago Law School, and Richard Posner, a distinguished member (and former Chief Judge) of the United States Court of Appeals for the Seventh Circuit. Stone described the ruling as "a partisan political decision, not a decision about the meaning of the United States

30. Paul D. Carrington, Of Law and the River, 34 J. LEGAL EDUC. 222 (1984).

31. Richard A. Posner, Overcoming LAw (1995).

32. Indeed, see Paul D. Carrington \& H. Jefferson Powell, The Right to Self-Government After Bush v. Gore, Duke University School of Law Public Law and Legal Theory Working Paper Series, Working Paper No. 26, Dec. 2001, at http://www.law.duke.edu/pub/selfgov/ (discussing the "personal selfish motives of the Justices that seem to the present authors to be obvious, unusual, and paramount").

What may be paradoxical is that at least some of the people who identified with, or at least were sympathetic to, Critical Legal Studies not only professed surprise but were even willing to sign public statements whose rhetorical force depended on a commitment to a decidedly non-CLS version of "the rule of law." I confess to being one of these persons, though I have also publicly confessed to having second thoughts about wrapping myself in the mantle of "the rule of law." See Jack M. Balkin \& Sanford Levinson, Legal Historicism and Legal Academics: The Roles of Law Professors in the Wake of Bush v. Gore, 90 GEO. L.J. 173, 195 (2001). 
Constitution, ${ }^{93}$ basing his allegation at least in part on the patent fact, given the general tenor of their constitutional jurisprudence, that three of the justicesChief Justice Rehnquist and Justices Scalia and Thomas-could not truly have agreed with the equal protection analysis set out in the per curiam opinion that they signed. ${ }^{34}$ As it happens, Posner agreed, blithely stating that the three Justices "don't believe in that equal protection stuff." Instead, he suggested, they signed the opinion because of the unseemliness that would have attended a shut-down of the election based on simply adding up the votes from one opinion (by Kennedy and O'Connor) rejected by seven Justices and another (by Rehnquist, Scalia, and Thomas) rejected by six Justices. "It's very difficult to argue constitutional law," said Stone in response, "with someone who defines himself as so cynical about constitutional law that he thinks it's legitimate for three justices of the Supreme Court to endorse an opinion that they believe to be false and unacceptable and not persuasive in order to avoid having an illegitimate result." ${ }^{37}$ Stone noted that he is "frequently asked by skeptical students: 'Isn't constitutional law just politics in black robes?' 'Don't the justices just vote their political preferences?' 'Isn't all this stuff about the Constitution really a charade?",38 He strongly intimated that he would now have to change his past responses, which, presumably, were critical of such cynical assumptions. $^{39}$ Posner, in response, professed not to "understand why constitutional law professors teach fairy tales to their students," one of which tales, presumably, is that abstract fidelity to law takes precedence over what Posner goes on to describe as achieving "practical solutions to practical problems." from Posner's other writings that he viewed the result of Bush v. Gore, even if not the opinion, as just such a "practical solution" to the alleged problem of political disorder threatening the United States if the election were not abruptly declared to be over. ${ }^{41}$ An obvious question, raised by the analyses of Posner and the "crits" alike, is why should we even bother with the rhetoric of "law," at least with regard to the most important issues facing our society? Why do we instead not go directly to the partisan policy (or political theory) arguments?

Thus, the primary question facing the contemporary constitutional analyst is whether one can really take the United States Constitution seriously as a source

33. Patricia Manson, Provost Stone and Judge Posner Discuss Judicial Decisionmaking, CHI. DAILY L. BULl. (May 24, 2001), at http://www.law.uchicago.edu/news/posner-stone-debate.html. At the time of the debate, Stone was still provost of the University of Chicago. He has subsequently stepped down from the position.

34. $I d$.

35. Id.

36. $I d$.

37. $I d$.

38. Id.

39. Id.

40. Id.

41. See Posner, supra note 19, at 162 ("Bush v. Gore may have done less harm to the nation by reducing the Supreme Court's prestige than it did good by heading off a significant probability of a presidential selection process that would have undermined the presidency and embittered American politics."). 
of genuine guidance. In putting it this way, I wish to register strong disagreement with the assertion of my friends Sam Issacharoff and Michael Dorf that "[t]he inescapable question of American constitutional law in the twenty-first century is, as it has always been, how to reconcile democracy and judicial review." " To the extent that they can be read to suggest that their "inescapable question" is in fact the primary question facing constitutional theorists, I think they are wrong inasmuch as their formulation may reinforce the all-toocommon tendency within the legal academy to ignore the fact that public officials occupying legislative and executive roles are, as a practical matter, far more important than are judges in giving actual meaning to the Constitution. In any event, whoever claims the mantle of constitutional interpreter must present a plausible notion of how (or whether) proffered interpretations differ from unmediated political preference.

Justice Cardozo once wrote that " $[\mathrm{t}]$ he great generalities of the constitution have a content and significance that vary from age to age" ${ }^{43}$ - and, I might add, even within a given age. Do these "great generalities" lend themselves to such wide variation of meaning as to be, as a practical matter, useless? At this somber moment, we may especially wonder how much law really speaks during times of war, especially to "front-line" political figures who, most likely, need not fear even the theoretical possibility of judicial review with regard to their decision-making (and, if history is any guide, they can expect acquiescence from the Court with regard to those measures that might ultimately show up in litigation).

We need consider only the statement of Senate Minority Leader Trent Lott, questioned about the extent of authorization given President Bush to respond to the events of September 11: It was basically inappropriate, he said, to "quibble" or "argue the legalisms. The American people expect us to act. They expect us to be a team." ${ }^{44}$ We have long been aware of the temptation to declare the silence of law in times of war. But the challenge of American Legal Realism and its progeny, including both Critical Legal Studies and Law and Economics, is whether it is plausible to believe that law speaks with sufficient clarity (that we do not independently choose to give it) even with regard to what suddenly seem like more mundane issues surrounding "the law of politics." Or, perhaps, the better way of putting the question is whether law "speaks" when we overtly ask it the kind of questions that are commonly raised in litigation, for, as I shall argue later, the law may sometimes speak in such deafening tones that it literally makes it impossible to hear anything else.

Thus, a major point of my remarks, to be spelled out in the final section, is that we should take far more seriously than is suggested by the Issacharoff-Dorf

42. Samuel Issacharoff \& Michael C. Dorf, The 2000 Presidential Election Part I: Can Process Theory Constrain Courts?, 72 U. COLO. L. REV. 923, 926 (2001).

43. Benjamin N. Cardozo, The Nature of the Judicial Process 17 (1921).

44. David G. Savage, Vietnam Ghost Haunts Senate; Resolution: McCain is Concerned About Broad Authority Granted to the President. Experts Say He Has Virtually a Free Hand, L.A. TimES, Sept. 16, 2001, at A14. 
formulation the adequacy of the Constitution under which we live. I must emphasize the radical tension between the two views that I will defend. One view accepts the possibility that the Constitution is, quite literally, meaningless in any strong sense, so that it is merely a blank slate (or "inkblot") on which ostensible "interpreters" sketch or project their own favored views of politics. But this "indeterminacy" critique, to which I have made my own contribution, is really quite irrelevant to-indeed, contradicted by-the consideration of certain basic issues that arise when we consider structural aspects of American government, including, of course, many that are linked with the electoral process.

Although Bush v. Gore is relevant to both questions, it is obvious how it highlights the first: At every level, whether we are discussing the judges themselves or academics commenting on their handiwork, there is a remarkably good, even if not perfect, ${ }^{45}$ fit between known partisan loyalties and the positions being taken on the defensibility (more or less) of the decision. To use the language of political science, "attitudinalism" seems overwhelmingly the better explanation both of the decision and the attempts to attack or defend it than does "legalism."

Although this symposium brings together some of the most interesting legal minds in the country, no one has the slightest expectation (or hope) that any of us will actually change one another's minds as to the basic doctrinal issues posed by Bush v. Gore. A basic question therefore is whether one can have a discussion of "the law of politics" that does not wrestle with the implications of Bush v. Gore and, concomitantly, whether the ensuing discussion can pretend to be about "law" rather than "politics."

\section{III}

\section{WOULD ROBERT MCCLOSKEY COMMEND BUSH V. GORE AS AN EFFECTIVE USE OF THE SUPREME COURT'S POWER?}

My "home culture" is that of the legal academy, and the most pervasive single dispute within that culture for at least a century has been whether one can draw a sharp distinction between law and politics. But, I also have a "second home" in the community of political scientists, who inhabit their own discipli-

45. Steven Bickerstaff, a colleague at the University of Texas Law School who is usually associated with the Democratic Party, has written a thoughtful defense of the decision that in significant ways tracks Posner's view that the situation was sufficiently confused, and the potential consequences sufficiently precarious, that judicial solution was warranted. See Steve Bickerstaff, Counts, Recounts, and Election Contests: Lessons from the Florida Presidential Election, 29 FLA. ST. U. L. REV. 425 (2001). I am aware of three articles by political conservatives that are critical of Bush v. Gore. See Gary Rosen, Reconsidering "Bush v. Gore," COMMENTARY, Nov. 2001, at 35 ("Republicans and conservatives ..., one suspects, will find it difficult to continue avowing their old judicial principles with a straight face. Phrases like 'judicial restraint' and 'strict construction' may not sound the same for some time."); Robert J. Pushaw, Jr., Judicial Review and the Political Question Doctrine: Reviving the Federalist "Rebuttable Presumption" Analysis, 80 N.C. L. REV. (forthcoming May 2002) (criticizing the Court for not recognizing that the dispute presented a "political question" inappropriate for judicial resolution); see also Ward Farnsworth, "To Do a Great Right, Do a Little Wrong”: A User's Guide to Judicial Lawlessness, 86 MinN. L. REV. 227 (2001) (a critique of Richard Posner's defense of the Court by someone who identifies himself as a conservative). 
nary cultures and, concomitantly, have their own ways of understanding legal events, including the processes of constitutional change.

I frame this part of my discussion as an inquiry into what Robert McCloskey might say about Bush v. Gore. Who was Robert McCloskey, and why should we care about what he would say about Bush v. Gore? McCloskey was a leading member of the Harvard Government Department in the 1950s and 1960s and wrote, among other works, the classic book, The American Supreme Court. ${ }^{46}$ He suffered a premature death in 1969.

McCloskey was my mentor during graduate school, and I have, over the past decade, worked to keep his splendid volume current by adding chapters to new editions that treat the developments beyond 1960, when the first edition was published. ${ }^{47}$ So, in asking what he would say about Bush v. Gore, I am in effect asking what $I$ will say about that case in the next edition of the book, given that my aim is to speak as much as I can in McCloskey's voice as a political scientist interested in the role of the Supreme Court in American constitutional development rather than in the traditional doctrine-oriented voice of the legal academic.

My first assumption was that I could cheerfully use McCloskey's ostensible voice to issue a denunciation of the decision, in which, given the tenor of my earlier remarks, I would take great pleasure. After all, McCloskey was a wellknown proponent of "judicial restraint." As the first (and, as yet, only) political scientist invited to write the "foreword" to the annual November review of the prior year's term published by the Harvard Law Review ${ }^{48}$ he took that opportunity to offer grave reservations about the Court's decision in the spring of 1962 to judicialize legislative districting. He suggested that it was putting its legitimacy, carefully regained after the fiascoes of the 1930s, at risk in biting off considerably more than it could chew (or necessarily expect to gain public support for). Key to understanding his concern was that he was strongly affected by the imbroglio of the New Deal period, when the Court came under an assault led by President Roosevelt himself. McCloskey was of the "switch-in-time-that-savednine" school, analyzing the Court's ability to protect itself against Roosevelt's court-packing plan by reference to its notable acceptance, in 1937, of major New Deal legislation.

At the very least, he hoped that Baker v. Carr would be interpreted to require only relatively modest changes on the part of the affected states. Needless to say, he was chagrined when only two years later, in Reynolds v. Sims, the Court declared the electoral systems of the vast majority of the states unconstitutional through adopting the "one person-one vote" norm. ${ }^{49}$ As suggested by my earlier remarks, McCloskey's analysis was not based simply on legal nice-

46. Robert G. MCCloskey, The AmericAn Supreme Court (1st ed. 1960).

47. See Robert G. MCCloskey, The American Supreme Court (2d ed. 1994; 3d ed. 2000).

48. Robert G. McCloskey, The Reapportionment Case, 76 HARV. L. REV. 54 (1962), reprinted in ROBERT G. MCCLOSKEY, THE MODERN SUPREME COURT 263 (1972).

49. 377 U.S. 533 (1964). 
ties; rather, he was fearful that the Court was once again slipping dangerously toward overestimating its own power. In his 1965 article, "Reflections on the Warren Court," McCloskey wrote of "the remarkable extent of the Warren Court's will-to-govern" American governmental and social process" that reached "heights of activism . . previously reached only by the Court of the 1920-1936 era." ${ }^{51}$ Indeed, McCloskey went on to suggest that the role assumed by the Warren Court was even "in some ways still more imposing" than that assayed by the earlier Court because it had become "a major initiative-producing agency of modern government. ${ }^{, 52}$ McCloskey also noted, however, the popular esteem for such innovative decisions as Brown v. Board of Education ${ }^{53}$ and Reynolds v. Sims. Indeed, "innovative" may be a euphemistic term; he in fact wrote that these were "constitutional rules [created] out of whole cloth." possibility that perhaps the proper lesson was that "America seems to have a so-far unsatiated appetite for government by judiciary."

Moreover, in a marvelously supple essay ${ }^{56}$ he suggested that "our evaluation of a Supreme Court decision ... ordinarily depends on one or more of three different judgment components." ${ }^{57}$ The first of these components is what we might refer to as traditional "legalism," that is, the "fit" between the decision in question and our ordinary notions of interpretive propriety. In addition, McCloskey offered two other components, the first involving "the question of power," the second, "the question of value." 58 In summary, he wrote, "[I]n criticizing a judicial action we say that the Court has misread the Constitution, or that it has overtaxed its power capabilities, or that it has chosen the wrong ethical solution." 59 Quite obviously, if it has done all three, there is no difficulty at all in criticizing —indeed, castigating - the decision in question. Difficulties emerge, of course, if the components seem to point in different directions.

At this point, the task of figuring out what McCloskey (and I, having chosen to play the role of faithful disciple) might say about Bush v. Gore becomes considerably more interesting. It gets more interesting still when one returns to one of the best known chapters of The American Supreme Court, in which McCloskey offers an account of Marshall's opinion in Marbury v. Madison. ${ }^{60}$

50. Robert G. McCloskey, Reflections on the Warren Court, 51 VA. L. REV. 1229 (1965), reprinted in MCCLOSKEY, supra note 48, at 355.

51. Id. at 342 .

52. Id. at 345 .

53. 347 U.S. 483 (1954).

54. MCCLOSKEY, supra note 48, at 355.

55. Id. at 365 .

56. See Principles, Powers, and Values, in 1964 Religion AND THE PUBliC ORder 3, reprinted in. MCClOSKEY, supra note 48, at 290.

57. Id. at 292.

58. $I d$.

59. $I d$.

60. 5 U.S. 137 (1803). One critic has termed McCloskey's account as "absurd" and "romanticized." David Engdahl, John Marshall's "Jeffersonian" Concept of Judicial Review, 42 DUKE L.J. 279 (1992). 
That account, I want to suggest, represents an early version of what today we have come to know as "rational choice" theorizing about the behavior of politicians and their institutions. I certainly do not purport to offer here a comprehensive or authoritative account of rational choice assumptions, but I do assume that rational choice theory includes some version of the following propositions:

a) All political actors have agendas of their own, ranging from crass desire for re-election to attaining majestic visions of what constitutes a truly admirable polity, and they respond with alacrity to various incentives (or disincentives) with regard to achieving their goals;

b) Politicians do not operate atomistically but instead must work in and through institutions;

c) The ambitions of any given politician, as James Madison suggested long ago in Federalist 51, ${ }^{61}$ tend to become attached to the interests of the particular institution within which he or she is serving, especially if one envisions oneself as spending a significant amount of time-perhaps even the remainder of one's active life-within the institution; and

d) Institutions must always be analyzed structurally, which is to say that any given institution-the presidency, an administrative agency, a branch of Congress, or the United States Supreme Court-is involved in a complex matrix that consists of a variety of competing institutions (and of political actors occupying those institutions). This means, among other things, that the "interests" of a particular institution may counsel, at any given time, either coalition with or opposition to other institutions (and their leaders), with the institutions in question offering a variety of incentives to cooperate, or at least disincentives against opposition.

Consider Marbury v. Madison ${ }^{62}$ in the context of these assumptions. As with my analysis of Bush v. Gore, I begin my comments by offering a dogmatic assertion: Marshall's opinion in Marbury is no more defensible than is the per curiam opinion (or the concurrence) in Bush v. Gore. As William Van Alstyne pointed out many years ago, ${ }^{63}$ significant questions suggest themselves with regard to various aspects of the opinion. One can begin, of course, with the absolutely remarkable conflict of interest presented by the spectacle of Marshall deciding on the legal status of a commission that he himself had signed, but failed to deliver to Marbury, while serving as John Adams' Secretary of State, the very office subsequently occupied by James Madison. I am skeptical of the quality of Marshall's specific arguments with regard to the meaning of Section 13 of the Judiciary Act of 1789 and the meaning of Article III of the Constitution, given

Although, as indicated below, I remain basically sympathetic to his account, for my purposes whether it is accurate in all respects is less important than its utility in providing insight into the way that McCloskey might approach Bush v. Gore.

61. The Federalist No. 51 (James Madison).

62. 5 U.S. 137 (1803).

63. William W. Van Alstyne, A Critical Guide to Marbury v. Madison, 1969 DuKE L. J. 1. 
that they rest on tendentious interpretations of misquoted texts. Like McCloskey, I think that what explains the decision-that James Madison was violating his duty by refusing to deliver the commission to William Marbury but that Section 13 was unconstitutional because it purported to place original jurisdiction in the Supreme Court to issue a writ of mandamus-is a desire by Marshall to have his cake and eat it too. That is, as a Federalist opponent of the despised Jefferson, Marshall wanted to level salvos questioning the President's integrity without, however, doing anything that might lead to the Jeffersonians successfully defying a judicial decree, not to mention Marshall's understandable fear that a contrary decision in the case could well lead to a Jeffersonianinspired effort at impeachment. Finally, as a Chief Justice wishing to enhance the power of his institution, Marshall, even in surrendering the particular battle to Jefferson, took great care to enhance the power of the Supreme Court by demonstrating its authority (and ability) to invalidate a law passed by Congress and signed by the President. This, according to McCloskey, made Marshall and the institution he loved the overall winner in the great political shoot-out. Given McCloskey's own view that judicial review, on balance, was a good thing, Marshall's strategic cleverness was a cause for celebration rather than critique.

So is it possible that Bush v. Gore would (or should) also elicit McCloskey's admiration rather than denunciation, especially after applying his own threepart test of legal principles, politics, and values? Just as much to the point, was I wrong, as a political scientist ${ }^{64}$ to describe, in the heated days of December, 2000, as "lunatic" the behavior of the Supreme Court in staying the recount on December $9{ }^{65}$ a term that I no doubt also used in conversation three days later when it shut down the election? Might it be the case that the Court, far from being "lunatic," was behaving in a perfectly rational, perhaps even commendable, fashion and that my inability to appreciate this represents a certain lack of analytic acuity on my part?

Most of the critics of Bush v. Gore have emphasized, as I did in my earlier remarks, the party identity of the Justices in the majority and have inferred that these Justices warmly approved of George W. Bush's becoming President and were therefore inclined to interpret the "great generalities" of the Constitution in a way that would bring about this happy ending. Note well that this does not require any conscious dissimulation on the part of the affected Justices. All it requires is a view of human psychology by which intellectual tensions will be resolved in a way that brings about the happiest of endings, in this case the movement of George W. Bush from the Governor's Mansion in Austin to the White House in Washington, D.C. This is to adopt a fairly raw version of "atti-

64. And possibly as a lawyer as well, though, as explained earlier, the legal analysis of Bush v. Gore is not my primary concern in this essay.

65. As I wrote to my fellow members of The Law and Courts Discussion List, "[T]he United States Supreme Court is staffed with lunatics, and the serious discussion now is how any of us who actually have the job of teaching this stuff maintain any respect whatsoever for a dangerously runaway Supreme Court." Posting of Sanford Levinson, SLevinson@mail.law.utexas.edu, to lawcourts-1@usc.edu (Dec. 9, 2000, 12:02:06 CST) (on file with author). 
tudinalism" by which judges simply (and sincerely) find attractive particular modes of lawtalk that serve, at the same time, as translations of their political preferences.

Although I do not want to reject in toto the power of such an "attitudinal" analysis, I want to place Bush v. Gore in a more fully developed institutional context. One must realize exactly how far removed from any Rawlsian "veil of ignorance" the Court was in December 2000. They not only knew the identity of the specific presidential candidate who would benefit from their decisions; they also knew the outcome of the elections with regard to the House of Representatives and the Senate of the United States. The first, of course, remained Republican, which meant not only that Dennis Hastert would continue to be Speaker of the House, but also, perhaps more significantly, that Tom DeLay would continue to be the de facto leader of the House through a combination of his ideological zealotry and demonstrated capacity to play the most hardball of politics against those he viewed as less than fully committed to his political agenda. The Senate was a bit more complex, given the uncertainty about who would represent the State of Washington in the Senate. It was clear, though, that the Democrats would have no more than fifty seats (as turned out to be the case until a Vermont Senator's entirely unexpected decision to leave the Republican Party), which meant that a Republican Vice President could assure the organization of the Senate for the Republicans.

Just as Marshall, according to McCloskey's analysis, had one eye on Congress and its capacity for exercising retribution against a decision they found unacceptable, one might suggest that the majority might have realized that a pro-Bush decision would guarantee it multiple friends. The most obvious would be George W. Bush, who, as President, would manifest his friendship by nominating to the federal judiciary (including, in due time, the Supreme Court itself) persons committed to the ideological agenda set forth by the Republican majority over the past decade. ${ }^{66}$

One ought not underestimate the importance of the House and the Senate as potential friends. Consider the fact that an "anti-Bush" decision would obviously not have pleased congressional Republicans. To be sure, Tom DeLay almost certainly could have engineered the election of George W. Bush, given the declared willingness of the Florida Legislature to ignore the results of the recount if it came up with the wrong outcome, that is, a Gore victory. ${ }^{67}$ And, if

66. A "full-scale" devotee of economic analysis might even point out that Bush and congressional Republicans could also manifest their esteem for the Court by supporting judicial pay raises that have been repeatedly sought by Chief Justice Rehnquist in recent years. I do not, however, impute any such motivation to any member of the Court.

67. This assumes, of course, that it would ultimately have been up to the House of Representatives to make the choice. Walter Dellinger has suggested, however, that a timely recount demonstrating a Gore victory in Florida would have led to a demand throughout the country for a sufficient number of Republican electors to defect (and vote for Gore) on December 18, 2000, if the Florida legislature had engaged in what most Americans would properly have recognized as a Republican putsch by ignoring the recount and naming their own electors. Conversation with Walter Dellinger, Professor of Law, Duke University School of Law, Durham, N.C. (Feb. 2001). I think there is much to this argument, 
Bush were destined to become President anyway, it is unthinkable that at least one callow Democrat in the Senate would not have joined fifty strong Republicans to name Richard Cheney as Vice President. But, of course, the very basis of the "pragmatic" defense of Bush v. Gore is that such a development would have been accompanied by significant political turmoil, perhaps widespread disorder, and that avoiding such political chaos was a value of fundamental importance.

Returning to the congressional Republicans, though, I suspect they were exceedingly grateful to the Court for getting them off the hook. They would have been most displeased if the Court had acted in a way that either (a) risked the possibility that Al Gore would become President after all, or (b) forced the congressional Republicans to take the political hit for defying the choice of a majority of American voters, who rejected George W. Bush, and, possibly, of a majority of Florida voters as demonstrated in a recount whose results would be contemptuously cast aside by a ravingly partisan Florida State Legislature. ${ }^{68}$

Bush v. Gore may have antagonized Al Gore and congressional Democrats, but, by definition, a defeated Al Gore would have few political resources at his disposal. The judicial majority might well be forgiven for doubting that congressional Democrats had sufficient political backbone to mount a serious attack. It was, after all, a Democratic Senate that capitulated to the cynical nomination of Clarence Thomas to replace Thurgood Marshall and, therefore, acquiesced to a Supreme Court whose center of gravity would shift (and stabilize) sharply to the right.

What about public opinion, insofar as one aspect of McCloskey's analysis involved the Court's interest in maintaining its stature in the minds of the general public? The importance of public opinion, for McCloskey, was demonstrated with special vividness in the rejection by the public of Franklin Delano Roosevelt's altogether understandable desire to pack the Supreme Court with justices more favorable to the political views that had just been overwhelmingly endorsed by the public in the election of 1936. So what might a "rational" justice, in December, 2000, believe about public opinion?

One obvious answer is that the American public was split roughly down the middle as to the comparative merits of George Bush and Al Gore as a potential President. If Democrats would likely be antagonistic to a decision favoring

though, of course, the Republican electors would have faced extreme pressures to remain faithful to their party.

68. Subsequent examination of the votes in Florida tends to support the proposition that the ultimate winner depends on complex decisions as to which votes should actually be counted and subsequently what ascertainment rules are adopted with regard to the given ballots. See, e.g., Counting the vote; Tracking Bush's Lead, NEW YORK TIMES, Nov. 27, 2000, at A16; Alison Mitchell, Over Some Objections, Congress Certifies Electoral Vote, N.Y. TIMES, Jan. 7, 2001, at 17. The "actualities" of the count, insofar as they are knowable, are of course irrelevant with regard to what able observers and politicians believed at the time was the case. Certainly, most Gore supporters were confident that a recount would help their champion; it is difficult to believe that Bush and his advisors would have chosen the course they did, with its inevitable potential for tarnishing the legitimacy of Bush's victory in the minds of most of his opponents, had they been truly confident that they could survive a statewide recount. 
Bush, one might expect significant approval from Republicans, leaving the Court's general approval relatively unchanged. The majority might have expected a lambasting from legal academics, most of whom are Democrats, but it could have discounted the importance of any such opposition; few people outside the academy are even remotely interested in the views of legal academics. Even the law professor's captive audience of students is far more likely to view the Court itself as more authoritative than their professors with regard to interpreting the Constitution.

Research conducted prior to the presidential election and then after the Court's decision in Bush v. Gore is extremely interesting. ${ }^{69}$ Gallup Poll numbers show that, around Labor Day of 2000, $62 \%$ of the public approved of the "way the Supreme Court is handling its job" and only $25 \%$ disapproved. ${ }^{70}$ At that time Democrats were more inclined to approve $(70 \%)$ than were Republicans $(60 \%){ }^{71}$ which lends credence to Lino Graglia's view ${ }^{72}$ that the Court remains, in at least some respects, considerably more liberal than is suggested by legal academics, who describe the current court as tending toward "revolution" in its commitment to ideological conservatism. ${ }^{73}$ Pre-election, Independent voters were least enthusiastic about the way the Supreme Court was handling its job, with $57 \%$ approval. $^{74}$

The Supreme Court's approval ratings dropped only three percentage points (to 59\%) after its decision in Bush v. Gore, though disapproval ratings jumped

69. See Herbert M. Kritzer, The Impact of Bush v. Gore on Public Perceptions and Knowledge of the Supreme Court, 85 JUdiCATURE 32, 38 (July-Aug. 2001) (citing a Gallup Poll); see also James L. Gibson et al., The Supreme Court and the U.S. Presidential Election of 2000: Wounds, Self-Inflicted or Otherwise (Feb. 20, 2002), at http://artsci.wustl.edu/ legit/index.html. For older studies regarding public opinion of the Supreme Court, which demonstrate a high level of public support, see Roger Handberg \& William S. Maddox, Public Support for the Supreme Court in the 1970s, 10 AM. POL. Q. 333, 337 (1982) (analyzing some explanations of public support for the Court based on national surveys conducted in 1972, 1974, and 1976 by the Center for Political Studies); Richard Lehne \& John Reynolds, The Impact of Judicial Activism on Public Opinion, 22 AM. J. POL. SCI. 896, 897 (1978) (citing the Dolbeare-Hammond study on public support for the Court). I am grateful to Chris Schroeder for bringing these earlier studies to my attention.

70. Kritzer, supra note 69, at 38.

71. Id.

72. See Lino Graglia, The Myth of a Conservative Supreme Court: The October 2000 Term (Fall 2001) (unpublished manuscript, on file with author). Chris Schroeder aptly comments, however, that

$[\mathrm{T}]$ here are actually three conservatisms represented on the Court (sometimes within a single justice): judicial role conservatism (classic judicial restraint ... ); ideological conservatism (aggressive reversal of bad precedents ... ); and Oakeshottian conservatism (continuity with past [is] valued; modest changes [are] better than abrupt... ). It's the inability of the ideological conservatives to gain a consistent majority that prevents this Court from meeting [Graglia's] standards [of a truly conservative Supreme Court].

E-mail from Chris Schroeder, Charles S. Murphy Professor of Law, Duke University School of Law, to Sanford Levinson (Sept. 24, 2001 7:48:56 EST) (on file with author).

73. See Balkin \& Levinson, supra note 29, at 1045. Larry Kramer suggests that "for most people approval or not of the Court turns on their perception of Roe v. Wade. [410 U.S. 113 (1973)] I think it is difficult to overstate the popular obsession for associating this issue with the Court, as if it were the only thing of moment the Court really does." E-mail from Larry Kramer, Professor of Law, New York University School of Law, to Sanford Levinson (Dec. 14, 2001 17:13:37 EST) (on file with author).

74. Kritzer, supra note 69 , at 38. 
$25 \%$ to $34 \% .^{75}$ Not surprisingly, Republican approval had jumped by a full onethird, from $60 \%$ to $80 \%$; presumably, only $15 \%$ remained sufficiently angry about the Court's legalization of abortion to declare that they "disapproved" of the Court. ${ }^{76}$ Democratic support had plunged by a similar percentage; now only $42 \%$ of Democrats approved of the Court, and $50 \%$ disapproved. Independents basically remained stable, going down from $57 \%$ approval in September to $54 \%$ in January. ${ }^{77}$

The most recent polling was done in June 2001, and the overall approvaldisapproval figures are now identical to what they had been almost the year before, $62 \%$ to $25 \% .^{78}$ Democrats are clearly learning to live with, if not to love, the Court, as $54 \%$ now approve and the $50 \%$ who had registered disapproval in January are now reduced to a mere $32 \% .^{79}$ Republican enthusiasm has diminished a bit, though it is still a robust $74 \%$. Independents' regard for the Court is at a peak of $59 \%$ approval and only $26 \%$ disapprove. ${ }^{80}$

Professor Kritzer analyzed a similar question involving "confidence" levels in various American institutions, including the Supreme Court. ${ }^{81}$ Quite remarkably, the public's "confidence" actually seemed to increase from 2000 to 2001: Whereas only $47 \%$ of the public indicated in June 2000 that they had a "great deal" or "quite a lot" of confidence in the Court (as against $49 \%$ who had only "some" or "very little"), $50 \%$ of the sample polled indicated such levels of confidence in June 2001. Indeed, even in mid-December of 2000, 49\% manifested the highest levels of confidence. Not surprisingly, the studies show that Democrats and Republicans responded differently to the Court's decision in Bush v. Gore. If, however, the Court was gambling that it could maintain broad public support even while throwing the election to George W. Bush and establishing ever better relations with the congressional Republicans, it was a winning decision. A group of distinguished political scientists, examining the effect of Bush v. Gore on the legitimacy of the Supreme Court, found "no evidence of a diminution in the level of loyalty the Court enjoys." ${ }_{22}$ Indeed, they offer as "the conclusions in which we have the greatest confidence" the following:

(1) the ruling in Bush v. Gore did not greatly undermine the legitimacy of the Court,

(2) probably because the effect of pre-existing legitimacy on evaluations of the decision was stronger than the effect of evaluations on institutional loyalty, and (3) institutional loyalty predisposed most Americans to view the decision as based on law and therefore legitimate.

One might offer the following as a collateral lesson of Bush v. Gore from the

75. Id. (analyzing post-election polls taken between January 10 and 14, 2001).

76. $I d$.

77. $I d$.

78. $I d$.

79. $I d$.

80. Id.

81. $I d$.

82. Gibson et al., supra note 69 , at 12 (emphasis in original).

83. Id. at 20 . 
perspective of a year later: $:^{84}$ The United States, jurisprudentially, is a distinctly "catholic" country in the sense that the public at large seems to accord a papallike authority to pronouncements of the Court. ${ }^{85}$ As someone who has, for the bulk of my scholarly career, been both describing the possibility of a "protestant" alternative and attempting to advocate its merits, I realize far better than before exactly the extent to which I am swimming upstream. It apparently never occurred to Al Gore to say, as some believed that Richard Nixon had suggested some quarter-century before, that he would honor only a "definitive" decision of the Court. ${ }^{86}$ Nor, of course, did any Democratic leader suggest that Congress should challenge the legitimacy of the Florida electors. Indeed, according to The New York Times, it was the Vice-President himself, who, as President of the Senate, "gaveled ... down" Representative Peter Deutsch, a Florida Democrat who was apparently taking the lead for "more than a dozen House members, most but not all of them black," who wanted to challenge the Florida results. ${ }^{87}$ Since no Senator was willing to join the House members, this meant that Congress could simply exercise without further ado its constitutional duty in January 2002 to count the vote and declare the identity of the next President.

In some ways this represents just another example of the ironic tricks that history often plays on "winners," who see their ostensible triumphs take on a decidedly different meaning as contexts change. It was, after all, liberals who joyfully emphasized the supremacy of the Supreme Court in the wake of Brown v. Board of Education ${ }^{88}$ and Cooper v. Aaron. ${ }^{89}$ In Cooper, the Court for the first time described itself as "ultimate interpreter" of the Constitution, a self-

84. That perspective must of course include the aftermath of September 11, a topic discussed at greater length infra in Part IV.

85. See SANFORD LEVINSON, CONSTITUTIONAL FAITH 37-46 (1988) (elaborating institutional differences between "protestant" and "catholic" constitutionalism).

86. See lucas A. Powe, American Politics And the Warren Court 45 (2000) (ascribing to "one of Richard Nixon's lawyers" the statement that Mr. Nixon would require "a definitive decision" with regard to his duty to turn over the incriminating tapes subpoenaed by the special prosecutor); EARl M. MAlTZ, THE CHIEF Justiceship OF WARREN BuRgER, 1969-1986 42 (2000) ("[I]t was widely feared that President Nixon was prepared to resist anything less than a unanimous decision from the court.").

At a speech I gave at the Institute of United States Studies at the University of London in May, 2001, a member of the audience made the brilliant suggestion that it may have been extremely significant that Gore was the son of a courageous Tennessee Senator who strongly supported the legitimacy of Brown v. Board of Education, 347 U.S. 483 (1954). Indeed, Senator Gore had strongly defended the Court's decision as "the law of the land," in contrast to those Southern representatives and senators who signed the so-called "Southern Manifesto" denouncing the decision or those Southern state officials who suggested that their states "interpose" their sovereignty to block enforcement of the decision. It would surely not be surprising if the younger Gore had been strongly socialized during his childhood years to accept the supremacy of the Supreme Court with regard to constitutional meaning. (With some modifications, of course, a similar analysis could be offered of President Clinton, who as a teenager could observe the militant opposition of Arkansas Governor Orval Faubus to school desegregation in Little Rock, which eventuated in the Court's decision in Cooper v. Aaron, 358 U.S. 1 (1958)).

87. Alison Mitchell, Over Some Objections, Congress Certifies Electoral Vote, N.Y. TIMES, Jan. 7 , 2001 , at 17.

88. 347 U.S. 483 (1954).

89. 358 U.S. 1, 18 (1957). 
description that included the assertions that Marbury had established the "basic principle that the federal judiciary is supreme in the exposition of the law [, a] ... principle [that] has ever since been respected by this Court and the Country as a permanent and indispenable feature of our constitutional system." $" 0$ The first assertion is debatable, though I believe that scholarly weight is in favor of a more modest interpretation of Marbury. ${ }^{91}$ The latter assertion is a quite remarkable overstatement, requiring the willful sweeping aside of repeated attacks on judicial supremacy from such luminaries as Andrew Jackson, Abraham Lincoln, Robert LaFollette, Franklin Roosevelt, and Edwin Meese. ${ }^{22}$ In the context of Cooper, which involved racist opposition to school desegregation, "one could easily sympathize with the Court's description of its role and indeed condemn those who challenged the authority (and domain) of its decision in Brown." "That being said, "if a student wrote such a statement in a final exam, it would receive a D at best." Still, one of the things we know about the United States Supreme Court is that, through the power of performative utterance, it can apparently create "historical truth" out of the same whole cloth that it creates "legal truth" for most Americans. Few liberals protested the Court's statement in Cooper; fewer still challenged the assertion of ultimate authority when it was repeated in Powell v. McCormack and U.S. v. Nixon. ${ }^{95}$ Similarly, political liberals were sharply critical of Attorney General Edwin Meese's attempt to distinguish the Constitution from judicial constructions of the Constitution. $^{96}$ Assertions of strong judicial supremacy continued to receive support from political liberals as late as 1992, as evidenced by the lack of liberal outcry over the authoritarian concurrence issued by Justices O'Connor, Kennedy, and Souter in Planned Parenthood v. Casey. ${ }^{97}$ Most liberals were pleased by the retention of constitutionally protected reproductive choice. ${ }^{98}$ It should not be surprising that O'Connor and Kennedy became part of the majority in Bush $v$. Gore, given their capacious understanding of the extent to which the country relied on the Court to offer definitive resolution of certain contentious issues. ${ }^{99}$ Perhaps members of the Court were aware of articles published while Bush $v$. Gore was under consideration suggesting that "the closest thing to unanimity is that the American people trust the U.S. Supreme Court more than any other in-

\footnotetext{
90. Id.

91. See, e.g., Robert Clinton, Marbury v. Madison And Judicial Review 5-6 (1989); SYLVIA SNOWISS, JUDICIAL REVIEW AND THE LAW OF THE CONSTITUTION 65-77, 121-25 (1990).

92. See LEVINSON, supra note 85, at 38-39.

93. Robert G. MCCloskey, The American Supreme Court 241 (3d ed. 2000).

94. Id.

95. United States v. Nixon, 418 U.S. 683, 704 (1974) (arguing that "our system of government requires that federal courts ... interpret the Constitution in a manner at variance with ... another branch"); Powell v. McCormack, 395 U.S. 486, 521 (1969) (asserting that the Supreme Court is the "ultimate interpreter" of the Constitution).

96. See Edwin Meese III, The Law of the Constitution, 61 Tul. L. REV. 979, 981-89 (1987). The response to Meese's speech is discussed in LEVINSON, supra note 85, at 39-42.

97. 505 U.S. 833, 833 (1992).

98. Id. at 834 .

99. See id. at 836 .
} 
stitution to make the final call about how to proceed." ${ }^{100}$ To reject this call from the people would itself have threatened the Court's high stature, or so a Justice might have thought. ${ }^{101}$

Let me summarize this part of my argument as follows: From the perspective of someone who adopts even a moderately rational-choice institutionalist approach to understanding the role (and behavior) of the Supreme Court, the decision in Bush v. Gore is not "lunatic"; indeed, it appears almost inevitable. Even if one agrees that the legal arguments are less than impeccable, considerations of judicial power strongly counseled doing exactly what the Court did. A contrary decision would have required almost monumental restraint on the part of the Court's Republican majority, given the overall institutional context in December 2000. Moreover, if one shares Richard Posner's dire warnings about the consequences of further uncertainty as to the identity of our new President ${ }^{102}$ then the decision easily passes the "value" test.

One powerful consequence of Bush v. Gore, then, is that it further entrenches the monarch-like status of the United States Supreme Court as "ultimate constitutional interpreter," with a monarch-like royal prerogative to ignore ordinary legal restraints when necessary to protect the public good. If one's notion of politics includes the opportunity of ordinary Americans and their political representatives to debate and resolve contentious constitutional issues, this is no small feature of our contemporary culture of constitutionalism. $^{103}$

100. Michael Tackett, Nation Waits on Supreme Court Justices Caught at Intersection of Law and Presidential Politics, CHI. TRIB., Dec. 12, 2000, at 1; see also Will Lester, Americans Split on Recount, Polls Say; Big Majority Trusts Court to Decide Fairly, New ORLEAns TIMEs PICAYUNE, Dec. 12, 2000, at 23 (emphasizing that public opinion polls showed that three-quarters of the public believed that the United States Supreme Court would decide Bush v. Gore fairly).

101. Mark Tushnet offers an interesting demurrer. He asks that we consider the possibility that, if "[t]he Court stays out, the political process grinds on in a way that completely discredits politicians, and (a) Bush becomes [P]resident - the more likely scenario-and the Court gets a Republican [P]resident and also enhances its own prestige relative to other institutions, or (b) Gore becomes [P]resident, Republicans say he stole the election, politics gets even uglier, and the Court looks like the really best institution we have (unless, as seems to me quite unlikely, people start blaming the Court for refusing to intercede and stop the madness)." E-mail from Mark Tushnet, Carmack Waterhouse Professor of Constitutional Law, Georgetown University Law Center, to Sanford Levinson (Oct. 4, 2001, 21:22:47 EST) (on file with author). There is nothing illogical about this scenario, but it strikes me as a much riskier way for the Court to enhance its prestige than the one it chose. I find it more likely than Tushnet does that many people would have placed blame on the Court for staying out of the fray on the basis of what could be considered legal technicalities. Moreover, by definition, the Tushnet strategy relies on leaving the House and Senate to stew in their own juices, scarcely a good way for the Court to make friends in those institutions.

102. POSNER, supra note 19, at 138-39, 143 (referring to "bizarre potential of the election standoff, had the Supreme Court not stepped in").

103. For an important delineation of the difference between "popular constitutionalism," by which the citizenry retains an important role in constitutional interpretation, and "judicial supremacy," which views any interpretive role as delegated entirely to the public's agents in the judiciary, see Larry D. Kramer, Foreword: We the Court, 115 HARV. L. REV. 1, 16-74, 90-110 (2001). 
IV

\section{CAN ANything LeSS Than a Full-Scale Train Wreck SERVE TO GENERATE A SERIOUS DisCUSSION OF AMERICAN POLITICAL INSTITUTIONS?}

The discussion thus far may (correctly) lead to the conclusion that I do not believe that law serves as a strong independent variable in explaining certain "momentous" decisions. Putting "scare quotes" around "momentous" is meant partly as a tip of the hat to Bruce Ackerman, whose theory of "constitutional moments" as a mode of explaining constitutional development I much admire and, more importantly, I believe is exemplary of the kind of theoretical work that more legal academics should be doing. ${ }^{104}$ Whether Ackerman is correct in all respects, he is clearly asking many of the right questions and has deepened our understanding both of what counts as, and what causes, significant constitutional transformations. ${ }^{105}$ However, to focus only on change, transformation, or transitions may itself be misleading in important ways. Any historian of culture, to be sure, must be aware of changes; this, indeed, is what defines one as an historian. But one must also borrow from classical anthropologists the insight that cultures are distinguished by deeply imbedded presuppositions that rarely, if ever, move to the forefront of consciousness, let alone become the subject of overt dispute. ${ }^{106}$ Bush v. Gore has made me more aware not only of "developments" in American constitutional culture such as the ever-increasing supremacy the Supreme Court has assigned to itself, but also of unchanging elements of our culture that are extremely important and deserve to be recognized, discussed, and even criticized.

I frame the question in this concluding section by slightly revising what I had initially suggested to Chris Schroeder as my title for the Currie Lecture, which was "Waiting for a Train Wreck: Culpable Negligence and the Design of American Politics." Part of my point is that the most important way that law structures politics is with regard to what might be termed "hard-wired" institutions. The central implication is that the issues practicing lawyers (and legal academics) tend to talk about when they talk about law may be relatively unimportant, at least as compared with the greater importance of hard-wired structures that we only rarely, if ever, discuss. For understandable, though I think ultimately indefensible, reasons, lawyers tend to concentrate on what can be litigated, which means, by definition, focusing only on the kinds of issues that can be presented to courts and explicated through standard-form legal analysis. This background helps to explain the contemporary concentration on campaign

104. See, e.g., Bruce Ackerman, Higher Lawmaking, in RESPONDING TO IMPERFECTION: THE THEORY AND PRACTICE OF CONSTITUTIONAL AMENDMENT 63, 71-74, $84-87$ (Sanford Levinson ed., 1995). Ackerman's general theory is spelled out in extraordinarily rich detail in 2 BRUCE ACKERMAN, WE THE PEOPLE: TRANSFORMATIONS (1998).

105. For criticisms of Ackerman's analysis, see Balkin \& Levinson, supra note 29, at 1079-83; Sanford Levinson, Transitions, 108 YALE L. J. 2215 (1999).

106. Think, for example, of the incest taboo. How many of us actually think about it at all, and who among us is willing to say that we as a society would be better off if we got rid of it? 
finance and racial (though not political) gerrymandering, two issues that instantly come to mind when one is asked about the law of politics.

Our failure to focus on the importance of hard-wired structures is just another example of the cost of accepting the view that constitutional theory must necessarily focus on judicial review. Implicit in that tradeoff is the assumption that law is basically reducible to what the Supreme Court says (or is likely to say) about a given issue. ${ }^{107}$ One might well question, incidentally, whether decisions by the Supreme Court are all that important in structuring the behavior of the public, including the segment of the public that is actively involved in politics. Gerald Rosenberg has notably described the Court as being only a "hollow hope" for those persons seeking basic changes in society. ${ }^{108}$ What might be most notable about Bush v. Gore, from this perspective, is how the Court proved to be a decidedly non-hollow hope for the Bush organization! That being said, we should recognize that hard-wired structures, imposed on the United States through the aegis of the Constitution, are impervious to what lawyers do best, which is present ingenious arguments for judicial resolution. Instead, these structures serve, in Max Weber's memorable phrase, as an "iron cage." Constitution may indeed constitute our polity in ways that we too often ignore-at our peril.

Let me return for a moment to my metaphorical use of the French Revolution. We are presented with an embarrassing overflow of possibilities with regard to analyzing those events. I began by noting the importance of the precise moment after the events when we begin our analysis. But, of course, analysts must also decide when before the events they want to begin their narratives. One could, after all, focus only on particular political intrigues in Paris and Versailles in 1789. Alternatively, one could adopt Alexis de Tocqueville's central point that understanding the French Revolution and the collapse of the ancien régime requires emphasis on developments in French political institutions over the previous century. ${ }^{110}$

Bush v. Gore is simply a particular epiphenomenal moment in a far more complicated narrative of American constitutionalism, which should indeed begin no later than $1787 .{ }^{111}$ Decisions made then that continue to be particularly

107. This is among the least happy legacies of Oliver Wendell Holmes, whose definition of law as simply a prediction of what courts will do, a defensible heuristic in many contexts, has been inflated to a jurisprudential maxim that has the consequence of blinding students and professors alike to law outside the courts. See Oliver Wendell Holmes, Jr., The Path of the Law, in THE Essential Holmes Collected Legal PaPers 160, 163 (Richard A. Posner ed., 1992) ("The prophecies of what the court will do in fact, nothing more pretentious, are what I mean by the law.").

108. See Gerald N. Rosenberg, The Hollow Hope 35 (1991) ("[T] he conditions enabling courts to produce significant social reform will seldom be present.").

109. Max Weber, The Protestant EthiC AND THE SPIRIT OF CAPITAlism 181 (Talcott Parsons trans., Scribner 1930).

110. See Alexis de Tocoueville, 1 The Old Regime And the Revolution (Francois Furet \& Franciose Melonio eds., Alan S. Kahan trans., 1998).

111. I should emphasize that this inquiry has very little, if anything, to do with the approach known as "originalism," which proclaims (or pretends) that we should, as a normative matter, feel obligated to conform to the desires of our long-dead ancestors. Rather, I am trying to understand what role par- 
relevant include the bicameral organization of the Congress (which has a great deal to do with explaining why Bill Clinton was impeached by the House of Representatives and then acquitted by the Senate); fixed presidential terms (which, in part, explains why he survived); the two-term limitation imposed on a President (which explains why Clinton did not run for re-election in 2000); the electoral college (which, of course, explains why George W. Bush is treated as the winner of the 2000 presidential election); equal voting power in the Senate (which explains why Clarence Thomas now sits on the Supreme Court and could provide the vital fifth vote to shut down the election); ${ }^{.12}$ and life-tenure of federal judges (which helps to explain, among other things, why federal judges can time their resignations to accord with their political preference as to likely replacements). Each and every one of these structural features of our political system has profound implications for the ways that politicians practice their crafts.

I am not particularly fond of some of these features of the U.S. political system. Indeed, Bill Eskridge and I have co-edited a book, Constitutional Stupidities, Constitutional Tragedies, which, among other things, includes a number of short essays identifying what the authors consider to be the most stupid feature of the Constitution and then justifying that designation.

Three such choices are certainly relevant to my central topic:

1) Jeff Rosen chose those parts of Article I and section 2 of the Fourteenth Amendment that allocate to states the primary responsibility for running elections for national officials. (It never occurred to him to mention Article II, section 1.$)^{113}$

2) Akhil Reed Amar picked the electoral college, in a contribution tellingly titled "A Constitutional Accident Waiting to Happen."

3) Third, I mention my own choice: the allocation, first by the 1787 Constitution and then by the Twelfth Amendment, to the House of Representatives of the power to break deadlocks in the electoral college on a one state-one vote basis. ${ }^{115}$ I concluded my essay-originally written in 1995-by analogizing this aspect of the Constitution to

a suspension bridge with a cable that is on the verge of tearing apart, with an untold capacity for damage to the innocent drivers below. If we are serious about building a sound bridge to the next millennium, then we should take care of this fundamental threat to the stability of our political system. The Constitution in

ticular long-past decisions of constitutional design — the most basic creation of "law"-might play, for good and for ill, in our present situation.

112. See Suzanna Sherry, Our Unconstitutional Senate, in Constitutional StUPIDITIES, Constitutional TRagedies 96 (William N. Eskridge \& Sanford Levinson eds., 1998)[hereinafter CONSTITUTIONAL STUPIDITES].

113. Jeffrey Rosen, Divided Suffrage, in CONSTITUTIONAL STUPIDITIES, supra note 112, at 81-83.

114. Akhil Reed Amar, A Constitutional Accident Waiting to Happen, in CONSTITUTIONAL STUPIDITIES, supra note 112, at 15-17.

115. Sanford Levinson, Presidential Elections and Constitutional Stupidities, in CONSTITUTIONAL STUPIDITIES, supra note 112, at 61-66. 
this respect is irredeemably stupid; our continued failure to recognize this and to do something about it now, before the full damage is done, is far worse. ${ }^{116}$

To put it mildly, nothing that occurred in this past year has changed my mind about the utter stupidity of one state-one vote. There is, however, one change: When I wrote in 1995, my concerns were dismissed as simple academic speculation, with no genuine application to the real world, especially if that world is defined by reference to what offers prospects for successful litigation. Because no one believed in the likelihood of a train wreck, no attention was paid to what many might have agreed, had they thought about it, is an unusually problematic feature of our Constitution.

The "no-train-wreck-can-happen" position, however, required a quite remarkable exercise of historical amnesia, not only of the elections of 1800 and 1824, which is perhaps understandable, but also, less understandably and far less forgivably, of the 1948 and 1968 elections. It is, after all, only blind luck that the extremely close Truman-Dewey and Nixon-Humphrey campaigns of those years in fact generated electoral vote majorities, given that Strom Thurmond, then Governor of South Carolina, won 34 electoral votes in 1948 as the champion of the States Rights Party, a feat topped in 1968 by the even more racist Governor of Alabama, George C. Wallace, who garnered 46 electoral votes as candidate of the American Party. ${ }^{117}$ Had 10,000 voters switched in California and 17,500 switched in Illinois, ${ }^{118}$ Truman would have lost his electoral vote majority. Likewise, in 1968 Richard Nixon prevailed in the race for California's electoral votes by approximately 224,000 out of 7.25 million votes. ${ }^{119}$ Had only 115,000 persons voted for Humphrey instead of Nixon, there would have been no majority winner in the electoral college, as Nixon would have had only 261 of the 270 votes necessary for election. Democrats had a majority of the state delegations in the House of Representatives in both the 81st and 91st Congresses,${ }^{120}$ but would anyone argue that the country at large would have easily accepted the designation by the House of Harry Truman or Hubert Humphrey? Vice President Humphrey, even with the hypothetical redistributions, would have lagged well behind the combined national vote of Richard Nixon and George Wallace, and even Nixon alone, had the hypothetical redistribution of votes been limited to the California 115,000. And consider the fact that the House delegations in those states that went for Wallace might well have been tempted to choose Nixon, perhaps as the result of 1824-like deals between

116. Id. at 65 .

117. United States Bureau of the Census, Historical Statistics of THE UNited States, COLONial Times TO 1970, PART 2, 1077 Series Y135-86 (1975).

118. Truman carried California, which then had 25 electoral votes, by only 18,000 popular votes, and Illinois, with 28 electoral votes, by 34,000 popular votes. Id.

119. Id.

120. Id. at 1083 Series Y204-210. 
Nixon and Wallace. Nixon's successful presidential race was, after all, based on an acknowledged "Southern strategy."

One might have thought that the elections of 1948 and 1968 would have generated nationwide conversation, followed by some measure of significant change, either in the electoral college process itself or in the subpart dealing with how the House would break election deadlocks. Even if one supports the overall concept of the electoral college, one might still accept the proposition that the final selection should be by a majority of the membership of the House rather than a majority of state delegations. There was, to be sure, some discussion at the time, and even proposals for constitutional change, ${ }^{122}$ but, as we know, no changes were implemented.

There are three possible explanations for the remarkable stasis of our institutions. One is that our institutions are easily capable of surviving the kind of "reflection and choice" that underlies the adoption of the Constitution. ${ }^{123}$ Under this explanation, the operative lesson, in Bobby McFerrin's famous words, is "Don't Worry, Be Happy," 124 a precarious position if one does not share such optimism. A second explanation rests on the importance of "precommitment strategies" that, by definition, rest on adhering to prior commitments whatever suboptimality might be attached in any given instance to such fidelity. ${ }^{125}$ Part of the point of a robust strategy of precommitment is that one does not return to assessing its actual value. The fact that it may be generally rational to adhere to suboptimal rules rather than adopt a more act-oriented utilitarianism does not really support the proposition that any and all existing precommitments deserve our support. Allowing constitutional amendments as a possibility within the political system requires the recognition that our existing institutions may be sufficiently imperfect as to warrant change. ${ }^{126}$

121. See, e.g., James T. Patterson, Grand Expectations: The United States, 1945-1974, 702 (1996) ("Much of [Nixon's 1968] campaign, like his choice of Agnew [as Vice President], reflected what pundits later called a Southern Strategy, which aimed to corral the backlash white vote in the South (and elsewhere).").

122. See Alexander M. Bickel, The New Age of Political Reform: The Electoral COllege, THE CONVENTION, AND THE PARTY SYSTEM 57-79 (1968).

123. See The Federalist No. 1 (Alexander Hamilton) (" $[\mathrm{I}] \mathrm{t}$ seems to have been reserved to the people of this country, by their conduct and example, to decide the important question, whether societies of men are really capable or not of establishing good government from reflection and choice, or whether they are forever destined to depend for their political constitutions on accident and force.").

124. Bobby McFerrin, Don't Worry, Be Happy, on SIMPLE PlEASURES (EMI Manhattan Records 1988).

125. The virtues of rule-based decision-making have probably been most fully developed by Fred Schauer. See Frederick SchAuer, Playing BY THE RUles (1991). It is worth noting that Schauer, in two articles co-authored with Larry Alexander, has written the most thoroughgoing defense of judicial supremacy as a desirable rule for the U.S. political system. See Larry Alexander \& Frederick Schauer, Defending Judicial Supremacy: A Reply, 17 CONST. COMMENTARY 455 (2000); Larry Alexander \& Frederick Schauer, On Extrajudicial Constitutional Interpretation, 110 HARV. L. REV. 1359 (1997).

126. See Introduction, RESPONDING TO IMPERFECTION: THE THEORY AND PRACTICE OF COnSTITUTIOnAL AMENDMENT 1-11 (Sanford Levinson ed., 1995). 
This last point, however, leads to my third explanation for our failure to respond adequately to train wrecks, even after they have occurred. The explanation lies in what I consider to be a very stupid feature of our Constitution, perhaps more important than any of the ones mentioned earlier. That is Article V, which makes it impossible, as a practical matter, to amend the Constitution in any serious way. ${ }^{127}$ As rational-choice theory would predict, relatively few people put significant political resources behind proposals for amendments that are, as a practical matter, doomed to failure. ${ }^{128}$ Admittedly, it is difficult to come up with empirical proof of the proposition that the relative infrequency of serious attempts to amend the Constitution is the result of Article V, particularly because there have been many proposals for constitutional amendments. ${ }^{129}$ Nonetheless, it is difficult to believe that contemporary politicians and academics who wish to be thought "serious" will devote much of their energy to fundamental constitutional revisions. ${ }^{130}$

Moreover, there is a deep psychological incentive to believe that what cannot be changed is quite all right. Maturity is sometimes defined as the serene acceptance of what cannot be changed. There is a connection between the de facto unchangeability of our constitutional order and the fact that even wellconnected members of the American political elite such as Lloyd Cutler and C. Douglas Dillon were unable to gain support for proposals contained in a book with the telling title Reforming American Government. ${ }^{131}$ A thin line separates "serenity" from abject denial. In any event, you can easily imagine which of these three explanations I find most plausible.

One message taught by the responses to the 1948 and 1968 elections is that even the patent possibility of train wrecks was not enough to generate significant attention. Still, one might think that the actuality of a train wreck might do so. Whatever else one might say about the events of September 11, 2001, they have certainly concentrated public attention on a variety of issues that people have written about for at least the past decade, beginning with the state of our airport security systems.

127. See Stephen M. Griffin, The Nominee Is . . Article V, in Constitutional Stupidities, supra note 112 , at 51 .

128. See Sanford Levinson, Designing an Amendment Process, in JOHN Ferejohn ET AL., CONSTITUTIONAL CUlTuRE AND DEMOCRATIC RULE 271-85 (2001).

129. See, e.g., JOHN R. VILE, REWRITING THE UNITED STATES CONSTITUTION: AN EXAMINATION of Proposals From RECONSTRUCTION TO THE PRESENT 2, 5-10 (1991).

130. Calls to amend the Constitution to allow school prayer or to criminalize flag burning scarcely count as proposing truly "fundamental" change, whatever the political passions connected with such issues.

131. ReForming AmericAn Government: THE Bicentennial PAPERs of the COMmitTeE ON The Constitutional System (Donald Robinson ed., 1985). See generally VILE, supra note 129, at 120,130. I should hasten to add that I am no fan of all of the proposals, such as the suggestion, for example, that the President be elected for a single six-year term. My point is that the proposals, to borrow David Hume's memorable phrase, basically "fell deadborn from the press." DAVID HUME, MY OWN LiFE (1777), quoted in BARTLETT's FAMILIAR QUOTATIONS 318 (Justin Kaplan ed., 16th ed. 1992). 
Response to the events of December 2000, including, of course, Bush v. Gore, has turned out to be all too reminiscent, however, of the earlier (non-) responses of 1948 and 1968. No train wreck, or so it is apparently thought, occurred, ${ }^{132}$ and few persons, a year later, seem compelled to ask questions about the soundness of our basic institutional structures. Proposed reforms have been quite modest. I do not want to denigrate the importance of better voting machines $^{133}$ and having more sensible times for casting votes, but such changes have nothing whatsoever to do with the deficiencies presented by the electoral college and the Twelfth Amendment. Almost no serious discussion was taking place about this prior to September 11; it is glaringly obvious that no such discussion will take place now, when our current discussions are directed to other, presumably more immediately threatening, subjects. And, of course, one of the things we may be learning in these discussions is exactly how malleable some of our ostensible pre-commitments in the Bill of Rights may turn out to be as a practical matter.

Let me turn, however, to one implication of "the law of politics" for our terrifying present situation. I have certainly emphasized my disdain for Bush $v$. Gore; it is too late to withdraw, even if I desired to, published arguments linking that disdain with doubts regarding the legitimacy of George W. Bush's occupying the White House. ${ }^{134}$ Even if we assume that I am completely mistaken, that Bush v. Gore is absolutely correct and that George W. Bush so clearly won Florida that he would not have needed any judicial intervention in the first place, this would have nothing at all to do with a very different question: Can we truly believe that Mr. Bush is actually the best person equipped to be President at a time when he must be the chief executive of a United States that is almost unimaginably different from the country that came to the polls in November 2000? I put it this way because I do accept Zhou En-lai's point that it is too early to tell what the ultimate consequences of the Bush Presidency will be ${ }^{.135} \mathrm{I}$ do not foreclose the possibility that my grandchildren will consider Bush alongside Abraham Lincoln and Harry Truman as rather unpromising politicians who in fact became great Presidents. As suggested earlier, however, we do not know the future, and our own assessments must be based on what we know now.

132. My friend Jack Balkin has recently described this as the "what hump?" response, by which he is referring to a scene in Mel Brooks' Young Frankenstein in which Dr. Frankenstein, upon meeting his new assistant Igor, refers to the latter's hump. Upon receiving the reply "what hump?", the good doctor realizes that Igor has simply been protected from any knowledge of what to others would seem a rather obvious feature of his physiognomy. Jack Balkin, Remarks at the Offensive Texts Panel, University of Texas Law School, Austin, Texas (Mar. 6, 2002). So if someone points to Florida as an example of a train wreck, one possible response is to say, with all innocence, "what train wreck?".

133. And, most certainly, better ballot design. No serious person believes that George W. Bush would have captured Florida had the infamous "butterfly ballot" not led to a remarkable upsurge in votes by retired Jews for Patrick Buchanan in Palm Beach County.

134. See, e.g., Balkin \& Levinson, supra note 29, at 1045 ("[W]e will call [George W. Bush] 'President' after he has successfully prevailed in an election conducted according to acceptable constitutional norms.").

135. See SCHAMA, supra note 1. 
You will recall that in those halcyon days of Autumn 2000, the greatest issue facing America, at least if one took the campaign speeches of Bush and Gore at all seriously, was the specific policy by which prescription drugs would be made available to older Americans, especially those residing in Florida. ${ }^{136}$ Neither candidate had anything remotely cogent to say about foreign policy, an issue of almost no concern to Americans at the time. ${ }^{137}$ To the extent that the election concerned issues of "character," one can easily concede that Mr. Bush has a number of fine qualities that could have led people to believe that he would be a good antidote to the less attractive aspects of the Clinton years. ${ }^{138}$ This being said, I think it is a sad truth that Mr. Bush does not possess the knowledge and experience of foreign policy or military affairs that one would want in a wartime President, particularly when the war is as complex as the one in which we are apparently involved. ${ }^{139}$ Nonetheless, Mr. Bush is the "only President we have," which means, in context, not only that he is the one person legally entitled to be called "President of the United States," but, far more importantly, that it is unthinkable that he will not occupy that office until the end of his term

136. Karen Branch-Brioso, Plans for Programs for Elderly are Turning Tides in Florida, ST. LOUIS PosT-Dispatch, Oct. 28, 2000, at 6; Richard Sisk, Al Touts Medicare Plan W. Calls Veep's Vow to Protect Seniors 'Fairy Tale,' DAILY NEWS (NEW YORK), Sept. 26, 2000, at 31.

137. Indeed, Governor Bush on one occasion proved himself unable to identify the leader of Pakistan's government, not surprising from a person who had spent astonishingly little time outside of the United States and who had exhibited almost no intellectual curiosity about most issues of public policy, including foreign affairs.

138. Perhaps it is relevant to note that, partisan Democrat though I may be, I left my ballot blank rather than vote for Bush's Democratic opponent in the 1998 gubernatorial election because I believed, as did most Texans, that Mr. Bush had been a reasonably good governor and that his Democratic opponent behaved unforgivably when he criticized Bush for having the temerity to pardon a convicted mass murderer who had received a death sentence. The reason for the pardon was simple: Two attorneys general, one Democratic, one Republican, had determined that Henry Lee Lucas had not in fact committed the one murder for which he was convicted and sentenced to death; he remains in prison for having committed several other murders that he did in fact commit. Then-Governor Bush behaved commendably, and his Democratic opponent behaved despicably in suggesting that it sufficed to kill Mr. Lucas on the basis that Mr. Lucas was a bad man.

139. I write these remarks many months after delivering the original lecture in October 2001. I will confess that he has been a more able "war President" than I believed would be the case in October, at least with regard to the particularities of the events in Afghanistan. I must also say, however, that the general Bush foreign policy strikes me as a shambles, in part because of a rapid return to "cowboy" style unilateralism that seems to express little more than contempt for the rest of the world, as least insofar as it is not willing to line up supinely behind the wishes of the United States with regard to the enemy $d u$ jour.

One common defense of Bush as President, that he is surrounded by good advisors, depends for its force on the premise that his advisors in fact agree among themselves and present him a unanimous recommendation. Given the fact that his advisors, like those of all other Presidents, scarcely seem to be of one mind on all important issues, one must still have confidence, whoever is President, to know whose advice is ultimately better. Because I do not have such confidence in Mr. Bush, I do not withdraw the harsh comments found in the text, even if I happily concede that he deserves some credit for his leadership in the early stages of the Afghan war (and concede as well that there is no reason to believe that a President Gore would have done better in that specific respect).

Normally, of course, footnotes like these would have no place in a law review article. They must be relevant, however, if the topic is whether the way that the Constitution structures the presidential term of office serves the country well or ill. 
unless there occur truly terrible contingencies that no one who loves this country could possibly wish for.

Why is Bush the "only President" we can even contemplate? The answer, I submit, is remarkably simple: Article II, section 1 provides that the President "shall hold his Office during the Term of four Years." Whatever our commitment to one or another theory of constitutional interpretation, whatever our sympathy toward deconstructionist or post-modernist approaches, all of us have been deeply socialized into an assumption that the person called President, whoever he may be, is entitled to remain in office unless events meriting impeachment or disability under the Twenty-Fifth Amendment take place. $.^{140} \mathrm{Nei}-$ ther of these constitutional possibilities has the slightest application to the current situation.

Part of the reason that replacing a sitting President is so unthinkable is the fact that the Constitution in effect establishes the President not only as head of government, but also as head of state, thereby capturing the emotional feelings other countries vest in monarchs or, as in Israel, so-called "figurehead" Presidents. Contrast the American President, in this regard, with the legal and emotional positions of the British Prime Minister, on the one hand, and Queen Elizabeth and her family, on the other. With regard to the Prime Minister, I am not referring merely to the ability of Parliament, through a vote of noconfidence, to bring down a government and force new elections. I find much more interesting and important the ability of the party in power to remove its leader and thus force the Prime Minister to resign. ${ }^{141}$

One cannot possibly understand the American political system without understanding the role of political parties, ${ }^{142}$ recognized most clearly in the Twelfth Amendment, which places the election for President and Vice President in separate tracks. Larry Kramer has called for the "constitutionalization" of political parties, by developing a more theoretical understanding of the contribution parties make to our political system and offering the parties protection against changes that would threaten these contributions. ${ }^{143}$ One possible contribution the political parties make to our political system is the ability to replace a President when there is good reason to believe that the country would be better off thereby.

140. Mark Tushnet correctly notes that "[t]here's nothing in the Constitution that precludes the (effective) removal of an unimpeached President who has become ineffective at governing and who has lost almost all support within his party. (Indeed, that's what happened with Nixon.)" E-mail from Mark Tushnet, to Sanford Levinson (Oct. 4, 2001, 21:22:47 EST) (on file with author). I believe that the parenthetical is crucial, for Nixon was certainly about to be impeached by the House of Representatives. It looked altogether likely at the time that enough Republican senators would vote to convict that he would be removed. No other U.S. President, of course, has resigned from the presidency.

141. For example, think of the dismissal by the Conservative Party of then-Prime Minister Margaret Thatcher and her replacement by fellow Tory John Major.

142. See Larry D. Kramer, Putting the Politics Back into the Political Safeguards of Federalism, 100 Colum. L. REV. 215, 268-78 (2000); Larry D. Kramer, Understanding Federalism, 47 VAND. L. REV. $1485,1522-42$ (1994).

143. Larry Kramer has informed me that he is currently at work on a manuscript, The Confidence of the People: Political Parties and the Constitution. 
You may agree or disagree with me. All of you would no doubt quickly, and rightly, point out that American party politics are decisively shaped both by federalism - that is, the existence of states - and by bicameralism and a separate presidency at the national level. You may even be right in totally rejecting my suggestion, but that really is not the main point. Far more important is the fact that a discussion of the potential wisdom of removing Bush from office, other than as part of the 2004 election process, will not happen, now or at any foreseeable future time. The very suggestion that we would be better served by installing as President a Republican other than George W. Bush sounds almost seditious under the precise terminology of the Sedition Act of 1798, which made it a criminal offense to bring into "disrepute" the President of the United States. ${ }^{144}$ Instead, we have been treated since September 11 to assurances that Bush has grown into a President in whom all of us should justifiably place great faith. I earnestly hope these assurances turn out to be correct, but I detect in them responses similar to those one makes to scared children who want to be told that their parents have whatever it takes to save them from all monsters, real or imagined. I believe that the ubiquity of such descriptions of Mr. Bush is the best evidence of the extent to which the structures established-as "law"by the 1787 Constitution are hard-wired within our collective consciousness. He is, indeed, the only President we can have, and we sleep far better at night if we believe that he is up to the job.

I am confident that no one would suggest jailing me for making these comments, as the First Amendment, too, may now be hard-wired. However, as John Stuart Mill pointed out, public opinion can be even more powerful than ordinary law in demanding ideological conformity and marginalizing unconventional thought. ${ }^{145}$ And public opinion, in important ways, is derived from the "veneration" that Americans direct at their Constitution, what I have elsewhere labeled "constitutional faith." 146

If this discussion sounds at best unconventional, at worst crazy or seditious, it is because we all live within the iron cage of unexamined aspects of the United States Constitution, including Article II and its stipulation that a President/head of state serves for four years. ${ }^{147}$ It is nothing short of bizarre that

144. See 1 Stat. 596 (1798), reprinted in PAUl Brest et AL., Processes of Constitutional DECISIONMAKING 60 (4th ed. 2000).

145. See JOHN STUART Mill, ON LiBERTY, in UTILITARIANISM, LIBERTY, AND REPRESENTATIVE GOVERNMENT 171 (Everyman's Library ed. 1951) (referring to "[t]he despotism of custom" as "everywhere the standing hindrance to human advancement").

146. LEVINSON, supra note 85; see also Sanford Levinson, "Veneration" and Constitutional Change: James Madison Confronts the Possibility of Constitutional Amendment, 21 TEX. TECH L. REV. 2443, 2443-60 (1990).

147. Let me try to demonstrate at least some measure of non-partisanship by emphasizing that I strongly disagreed — indeed was quite furious — with many of my (liberal) friends who argued in 1998 that Bill Clinton had a constitutional right to complete his term unless he had committed an offense that would have been deemed impeachable by the Founding generation in 1787. Although I ultimately opposed Clinton's impeachment (and conviction), I had, until October 1998, supported his resignation because I doubted that he could be the effective President very much needed by the United States. I changed my mind, partly because of my distaste for many of Clinton's Republican opponents, but, I 
one's commitment to "precommitment" would necessarily lead to supporting a President's continuation in office even if one believed that he had lost any kind of political mandate and that his presidency had become genuinely harmful to vital national interests.

It is no denigration of the founding generation to say that they did not construct a set of institutions each and every one of which necessarily serves us well some 210 years later. It is a denigration of our own generation that we seem incapable of a long-overdue national conversation about these institutions and the possibility that they are not only "suboptimal," but also, and far more significantly, seriously dysfunctional. Any discussion of the "law of politics" should spend at least some time focusing on the most basic law set out in the Constitution with regard to our fundamental structures. It is not that campaign finance and racial gerrymandering are unimportant; they surely are. Rather, there is simply little reason to believe that they pose the same threat of train wrecks as do features of our political system that we almost never bother talking about. It is well past time for such conversations to begin. 